\title{
EFFECT OF CAPITAL STRUCTURE AND PROFITABILITY TO THE VALUE OF COMPANY
}

\author{
Irma Christiana $^{1}$, Desy Herawati Matondang ${ }^{2}$ \\ University of Muhammadiyah Sumatera Utara \\ irmachristiana@umsu.ac.id ${ }^{1}$,desyherawati3895@gmail.com ${ }^{2}$
}

\begin{abstract}
This research is conducted to examine the influence of capital structure (Debt to Equity Ratio) and profitability (Return On Assets) to company value (Price Book Value) at food and beverage company listed in Indonesia Stock Exchange period 2012-2016. The approach used in this study is an associative approach, the population in this study were as many as 17 companies. Samples were taken using purposive sampling method to obtain 10 companies as sample. Techniques Data analysis in this study using regression analysis. The results showed that the capital structure (Debt to Equity Ratio) has no effect and not significant to firm value (Price Book Value) with significance less than 5\%. While profitability (Return On Assets) has a significant effect on firm value (Price Book Value) with significance greater than 5\%. Simultaneously the capital structure (Debt to Equty Ratio) and profitability (Return On Assets) effect on firm value (Price to Book Value). The predictive ability of the two variables to the company value is $23.9 \%$ as indicated by the magnitude of $R$ Square while the remaining $76.1 \%$ is influenced by other factors not examined in this research.
\end{abstract}

Keywords: Debt To Equity Ratio, Return On Assets, Price To Book Value

\section{INTRODUCTION}

The purpose of the company established is none other than to increase the prosperity of the owners or shareholders. The wealth of the owner or shareholder is measured by the value of the company, which is reflected in the stock price. The higher the stock price the higher the value of the company and the higher the value of the company then the shareholder's welfare will increase. According to Aries (2011) the value of the company is the result of management work of several dimensions including net cash flow from investment decisions, growth and capital cost of the company. can be measured by stock prices using a ratio called rating ratio. The methods used to measure company value include Price Earnings Ratio (PER), Price Book Value (PBV) and Tobin's Q.

In this study, the company's value is measured by using Price to Book Value (PBV). Price Book Value (PBV) is a comparison between market value and book value per share. The advantages of this method can, among other things, be used to assess all types of companies and can also be used in companies that have the same accounting standards in an industry sector, and can even be used in companies with negative revenue or negative cash flow.

According to Asnawi and Wijaya (2010) Price Book Value (PBV) is a comparison between market value and book value. As the book value (all presented in the financial statements) can be different from market value (represented by price) ". Firms that have higher Price Book Value (PBV) value indicate that the company's performance in the future is considered more prospective by its investors. Corporate value is one of them influenced by the company's capital structure. Capital structure is needed to increase the value of the company because the establishment of capital structure in the company's funding policy determines the profitability of the company (Yuliana, et al, 2013). The capital structure can be expressed in the Debt to Equity Ratio (DER).

Debt to Equity Ratio (DER) is ratio of ratio between total debt to own capital. Debt to Equity Ratio (DER) is used to measure the ratio of total debt to total assets; in other words, how much debt asset management company, also to analyze the company's ability against the obligations of others. Debt to equity ratio (DER) reflects the ability of the company by using all its obligations indicated by some part of the capital itself used to pay the debt. By therefore, the lower the DER (debt to equity ratio), the higher the company's ability to pay all of its obligations. In the end an increase in debt will be affect the level of net income available to shareholders including dividends to be accepted (Frederik et 
al, 2015). Meanwhile, according to Kashmir (2015) The higher the Debt to Equity Ratio (DER) ratio, the more debt for the company to get additional loans because it is feared the company is not able to cover its debts with its own assets

In addition to capital structure, corporate value is also influenced by the size of the profitability obtained by the company. Profitability is the ability of a company to generate profit over a certain period. Weston and Copeland (1997) define the probability of the extent to which firms generate profits from sales and corporate investments. If the profitability of the company is good, then stakeholders consisting of creditors, suppliers, and investors will see the extent to which the company can generate profits from sales and investment companies. Profitable can be expressed in Return on Assets (ROA).

Return On Assets (ROA) is a ratio that measures how efficiently a company manages its assets to generate earnings over a given period. The greater the value of Return On Assets of a company, indicating the number of assets or property owned by the company. This ratio is to evaluate the effectiveness and efficiency of the company's management in managing all the assets of the company. According Sudana (2011) Return On Assets (ROA) shows the ability of the company by using all assets held to generate profit after tax. This ratio is important for management to evaluate the effectiveness and efficiency of the company's management in managing all the assets of the company. If the profitability of the company is good then the stakeholders consisting of creditors, suppliers, and investors will also see the extent to which the company can generate profits from sales and corporate investments. With good company performance will also increase the value of the company (Prasetyorini, 2013).

From the report of the company can be seen that the variables Debt to Equity Ratio, Return on Assets and Price to Book Value showed a fluctuating trend during the period of observation 2012-2016, this is due to the uncertainty of corporate performance shown by the trend of financial ratios are very volatile.Price to Book Value (PBV) fluctuates, if seen from the average value per year obtained by 3.62, then the year 2012, 2015 and 2016 value price to book value below the average value but the results remain above 1 (one). Price to Book Value (PBV) is the ratio between stock price to book value. If a company has a PBV above $1(>1)$, then the stock price of the company is valued higher than the book value that describes the company's performance is getting better in the eyes of investors. The change of Price to Book Value is due to a change of fundamental factors affecting Price to Book Value as the price per share decreases.

From the company report, when viewed from the average value of Debt to Equity Ratio (DER) of $0.90 \%$., 2013, 2014 and 2015 DER value is above the average value. This indicates that the amount of debt the company increases and will decrease earnings.

From the company report, the average value of Return on Assets (ROA) of 10.12\%, 2014 and 2015 value of ROA below the average value. Return on Assets is down will cause the value of Price to Book Value. This indicates that the company is less able to optimize its performance.

However, the change of these factors is inconsistent. If viewed from the value of Debt to Equity Ratio (DER) in 2013 and 2014 is above the average should the value of Price to Book Value (PBV) decreased but actually experienced an increase. If viewed from the value of Return on Assets (ROA) in 2014 below the average value should the value of Price to Book Value (PBV) also decreased but actually experienced an increase.

\section{RESEARCH PURPOSES}

Based on the problems that have been mentioned above, as for the purpose of research that is done are : a). To know and analyze the influence of Debt Equity Ratio (DER) to Price Book Value (PBV) in Food and Beverage company listed in Indonesia Stock Exchange. b). To know and analyze the influence of Return On Asset (ROA) to Price Book Value (PBV) at Food and Beverage company listed in Indonesia Stock Exchange. c). To know and analyze the influence of Debt to Equity Ratio (DER) and Return On Assets (ROA) simultaneously to Price Book Value (PBV) at Food and Beverage company listed in Indonesia Stock Exchange.

\section{THEORETICAL STUDY}

Company value is basically measured from several aspects, one of which is the stock market price because the stock market price of the company is the overall equity owned. This can be an investor decision on the value of the company. In this study, the measurement of firm value using Price Book 
Value (PBV). Price Book Value (PBV) is used to measure the market value of the book value. According to Fahmi (2015) states that: Price Book Value is the result of comparison between stock price and book value. Companies with high equity returns typically sell their shares with a higher book value doubling than other low-returning companies. Furthermore, according to Asnawi and Wijaya (2010) concerning Price Book Value stating that: Price Book Value (PBV) is a comparison between market value and book value. As the book value (all presented in the financial statements) can be different from market value (represented by price).

Capital structure is a balance between the use of loan capital consisting of short-term debt is permanent and long-term debt with own capital. The capital structure is a combination of long-term debt and equity, and ignoring short-term debt (Asnawi, 2010). measurement of capital structure using Debt to equity ratio (DER). Debt to equity ratio (DER) is used to measure the ratio between total debt to equity. According to Kashmir (2015) concerning Debt to Equity Ratio states that: Debt to Equty Ratio is the ratio used to assess debt with equity. This ratio is sought by comparing between all debts, including current debt with equity. Meanwhile, according to Guinan (2010) on the definition of Debt to Equity Ratio states that: Debt to Equity Ratio (DER) is a measure of corporate financial leverage, calculated by dividing total liabilities with total equity or shareholder capital. It identifies the proportion of stocks and debt in the financing of the company's assets. From the earnings of experts can be concluded that the Debt to Equity Ratio is the ratio to measure the total debt with the total capital itself. The higher Debt to Equity Ratio indicates that the greater the company's expense to the creditor.

Sartono (2010) states that: Profitability is the ability of a company to earn profits in relation to sales, total assets and own capital. The methods used to measure profitability are Gross Profit Margin (GPM), Net Profit Margin (NPM), Return On Asset (ROA), Return On Equity (ROE), Return On Investment (ROI) and Operating Profit Margin (OPM). In this study, the measurement of profitability using Return On Assets (ROA). Return On Asset (ROA) is used to measure the ratio between net income to total assets. According to Sudana (2011) on Return On Assets (ROA) states that: Return On Assets (ROA) shows the ability of a company to use all of its assets to generate profit after tax. This ratio is important for the management to evaluate the effectiveness and efficiency of the company's management in managing all of the company's assets. Return On Assets (ROA) states that: Return On Investment (ROI) is also called Return On Assets (ROA), is a ratio that shows the results (return) on the amount of assets used in the company. Return On Investment (ROI) is also a measure of management effectiveness in managing its investment (Kasmir,2012). Thus it can be concluded that Return On Asset is the ratio to measure net profit after tax with total assets to determine the ability of companies in managing assets owned to generate profits.

\section{The effect of Debt To Equity Ratio on Price to Book Value}

The company would expect to be able to pay its obligations in every operational run. According to Guinan (2010) states that: "Debt to Equity Ratio (DER) is a measure of corporate financial leverage, calculated by dividing total liabilities by total equity or shareholder capital". It identifies the proportion of stocks and debt in financing the company's assets. The greater the Debt to Equity Ratio shows the higher the obligation and the lower Debt to Equity Ratio will show the higher the company in fulfilling its debt.

Corporate value can also be influenced by the size of the leverage generated by the company. This means greater leverage indicates an increasing risk of investment. Leverage needs to be managed because high debt usage will increase the value of the company. This is reinforced by the results of research conducted by Karina Meidiawati and Titik Mildawati (2016) and Ni Made Suastini, et al (2016) stating that capital structure has a significant positive effect on firm value, based on the development of hypotheses can be formulated hypotheses as follows:

H1: Debt to equity ratio has a positive and significant effect on price to book value

\section{The effect of Return on Assets on Price to Book Value}

In every company's operation, every company can certainly expect profit or profit, because with the profit the company can continue its operational activities. According to Sudana (2011) states that: "Return On Assets (ROA) indicates a company's ability to use all of its assets to generate profit after tax". This ratio is important for the management to evaluate the effectiveness and efficiency of the company's management in managing all the assets of the company. 
Return On Asset reflects the ability of the company to generate profits based on assets owned. High profits in a company indicated the company has good prospects, it will have an impact on rising stock prices so as to increase also the value of the company. The higher Return On Assets ratio will appeal to investors so they will be interested to invest in the company. With shares of interest to investors will increase the value of the company.

The results of Chaidir's research (2015) and Isabella Permata Dhani and A.A Gde Satia Utama (2017) show that Return On Assets (ROA) have a significant positive effect on Price Book Value (PBV). Increased attractiveness of the company makes the company is in demand of investors, because the rate of return will be greater, based on the development of hypotheses can be formulated hypotheses as follows:

H2 : Return on assets has a positive and significant impact on price to book value

\section{The effect of Debt to Equity ratio and Return on Assets on Price to Book Value}

Debt to Equty Ratio is the ratio used to assess debt with equity. This ratio is sought by comparing between all debts, including current debt with equity (Kasmir,2015). According to Sudana (2011) states that: Return On Assets (ROA) indicates the ability of a company to use all of its assets to generate profit after tax.

Corporate value can be affected by the size of the leverage. Increased leverage indicates an increasing risk of investment. And a high profit in a company will have an impact on rising stock prices so as to increase the value of the company. The result of Syarinah (2017) study stated that Debt to Equity Ratio and Return On Assets simultaneously have a significant influence on Price Book Value, based on the development of hypotheses can be formulated hypotheses as follows:

H3 : Debt to equity ratio and return on assets has a positive and significant impact on price to book value

\section{RESEARCH METHODS}

The research approach used in this research is an associative approach, which aims to analyze the relationship of a variable with other variables. The population in this research are 17 food and beverage companies listed in Indonesia Stock Exchange, the sampling is done by purposive sampling method, it can be determined the sample in this study amounted to 10 food and beverage companies listed in Indonesia Stock Exchange period 2012-2016.

While the method of data analysis using Multiple Linear Regression analysis, but previously done Classic Assumption Test starting from normality test, multicollinearity test, and heteroscedasticity test, followed by hypothesis testing ( $\mathrm{t}$ test and $\mathrm{F}$ test) and coefficient of determination.

\section{RESULTS AND DISCUSSION}

\section{Results}

The classical assumption test starts from the normality test using P-Plot graph, the result of normality test of data shows the spread of data points approaching the diagonal line, so it can be concluded that the regression model is normal distribution and feasible to be analyzed. The next classical assumption test is a multicollinearity Test where the VIF value is high (because VIF $=1$ tolerance). Common cutoff values used to indicate the presence of multicollinearity are tolerance values of 0.10 or equal to VIF > 10. The result of multicollinearity test obtained VIF debt to equity ratio and return on asset is $2,071<$ 10 , hence there is no multicollinearity. The next classical assumption test is the Heteroscedasticity test, by looking at the Scatterplot chart if there is no clear pattern, and the point spreads above and below the number 0 on the $\mathrm{Y}$ axis, hence there is no heteroscedasticity, thus no heteroskedasticity occurs in this regression model.

After testing the classical assumption, it can be concluded that the model can be used to perform multiple regression analysis. The result of multiple linear regression analysis can be as follows: $\mathrm{Y}=\mathrm{a}+$ $\mathrm{bx} 1+\mathrm{bx} 2+\mathrm{e}$, then $\mathrm{Y}=-0,230+1,451 \mathrm{X} 1+0,251 \mathrm{X} 2+\mathrm{e}$. The interpretation of the equation is First, the constant of -0.230 indicates that if all Debt to Equity Ratio independent variables, and Return On Assets, are assumed to be zero, then the Price Book Value value is -0.230 . Second, the coefficient of Debt to Equity Ratio of 1.451 with the direction of positive relationship indicates if the Debt to Equity 
Ratio variable increased by $100 \%$, then Price Book Value increased by $145.1 \%$ with the assumption that the other independent variable is zero. Third, the Return On Assets Coefficient of 0.251 with the direction of positive relationship shows if the variable Return On Assets increased by $100 \%$, then Price Book Value increased by $25.1 \%$ assuming other independent variables are zero.

Testing the hypothesis of this study is debt to equity ratio and return on asset affect the price to book value at food and beverage companies listed on the Indonesia Stock Exchange in 2012-2016. Testing results hypothesis Test statistics t can be seen in table 1 below:

Tabel 1. t-Test Result

\begin{tabular}{|c|c|c|c|c|c|c|}
\hline & \multirow[t]{2}{*}{ Model } & \multicolumn{2}{|c|}{$\begin{array}{l}\text { Unstandardized } \\
\text { Coefficients }\end{array}$} & \multirow{2}{*}{$\begin{array}{c}\begin{array}{c}\text { Standardized } \\
\text { Coefficients }\end{array} \\
\text { Beta }\end{array}$} & \multirow[b]{2}{*}{$t$} & \multirow[b]{2}{*}{ Sig. } \\
\hline & & B & Std. Error & & & \\
\hline \multirow[t]{3}{*}{1} & (Constant) &,- 230 & 1,715 & &,- 134 &, 894 \\
\hline & DER & 1,451 & 1,180 & 225 & 1,229 & 225 \\
\hline & ROA & ,251 & ,074 & ,625 & 3,415 & ,001 \\
\hline
\end{tabular}

Hypothesis 1: Table 1 shows that the effect of debt to equity ratio on price to book value by determining the value of $\mathrm{t}$ table is obtained by looking at df (nk), $50-2=48$ then the value of $\mathrm{t}$ table equal to 2.010 with probability $\operatorname{sig}=0.05$. obtained $t_{\text {count }}<t_{\text {table }}$ that is $1,229<2,010$ or probability significant level 0,225>0,05 it indicates $\mathrm{H}_{0}$ accepted and $\mathrm{H}_{\mathrm{a}}$ rejected it can be concluded that debt to equity ratio (X1) is partially not influential and not significant to price to book value (Y).

Hypothesis 2: Table 1 shows that the effect of return on assets on price to book value by determining the value of $\mathrm{t}$ table is obtained by looking at $\mathrm{df}(\mathrm{nk}), 50-2=48$ then the value of $\mathrm{t}$ table equal to 2.010 with probability $\operatorname{sig}=0.05$. obtained $\mathrm{t}_{\text {count }}>\mathrm{t}$ table that is $3,415>2,010$ or probability significant level $0,01<0,05$ it indicates $\mathrm{H}_{\mathrm{a}}$ accepted and $\mathrm{H}_{0}$ rejected it can be concluded that return on asset (X2) is partially influential and significant to price to book value (Y). Likewise, by looking at the value of beta among other variables the largest contribution is given by the variable return on assets with a value of 0.625 .

Hypothesis 3: To see the effect simultaneously between variable of debt to equity ratio and return on assets to price to book value can be seen from $\mathrm{F}$ test (simultan), result obtained from calculation using SPSS tool, obtained value which can be seen in Table 2 .

Tabel 2. F-Test Result

\begin{tabular}{|c|c|c|c|c|c|c|}
\hline & \multicolumn{6}{|c|}{ ANOVA $^{b}$} \\
\hline & Model & $\begin{array}{l}\text { Sum of } \\
\text { Squares }\end{array}$ & df & Mean Square & $\mathrm{F}$ & Sig. \\
\hline \multirow[t]{3}{*}{1} & Regression & 79,058 & 2 & 39,529 & 7,388 &, $002^{\mathrm{a}}$ \\
\hline & Residual & 251,481 & 47 & 5,351 & & \\
\hline & Total & 330,539 & 49 & & & \\
\hline
\end{tabular}

a. Predictors: (Constant), ROA, DER

b. Dependent Variable: PBV

Test $F$ in the above table obtained $F_{\text {count }}$ value of 7.388 with significant 0.002 while $F_{\text {tabel }}$ is known at 4.46. Based on these results can be seen that $F_{\text {count }}>F_{\text {table }}(7,388>4,46)$ and significant value of $(0.002$ $<0.05)$ so that $\mathrm{H}_{0}$ is rejected and $\mathrm{H}_{\mathrm{a}}$ accepted. So it can be concluded that the variables Debt to Equity Ratio and Return On Assets jointly affect the Price to Book Value. 


\section{Coefficient of Determination}

Tabel 3. Coefficient of Determination Result

\begin{tabular}{|c|c|c|c|c|}
\hline \multicolumn{5}{|c|}{ Model Summary } \\
\hline Model & $\mathrm{R}$ & R Square & $\begin{array}{l}\text { Adjusted R } \\
\text { Square }\end{array}$ & $\begin{array}{l}\text { Std. Error of } \\
\text { the Estimate }\end{array}$ \\
\hline$\overline{1}$ &, $489^{a}$ & ,239 & 207 & 2,31315 \\
\hline
\end{tabular}

Based on table 3, $\mathrm{R}$ value is the correlation coefficient with the value of 0.489 or $48.9 \%$ indicates that the correlation or relationship between independent variables ie debt to equity ratio and return on asset with the dependent variable is the price to book value ratio is moderate. For more accurate prediction influence of debt to equity ratio and return on assets in this research can be seen at value of $\mathrm{R}$ Square that is equal to 0,239 or $23,9 \%$ influence of independent variable to dependent variable and rest $76,1 \%$ influenced by other variables that not are included in this research.

\section{DISCUSSION}

\section{The effect of Debt to equity ratio on Price to book value}

Debt to equity ratio is used to measure the extent to which the company is financed by debt (Syamsudin, 2011). A high debt to equity ratio will have an impact on reducing the net profit that will be enjoyed by the shareholders because some profit is used to pay interest expense. The greater the debt to equity ratio indicates that the level of debt received by the company is also greater. Funds obtained from debt are usually used by companies to run their activities and expansion in the hope of generating high profits.

The inability of debt to equity ratio to price to book value indicates that most investors want short-term profit in the form of capital gain so that in considering the purchase of shares does not consider the debt to equity ratio of the company, but follow the trend in the market. In other words, the debt to equity ratio is not a major consideration for investors when it comes to determining investment or buying shares. This is because most investor orientation is capital gain oriented instead of dividend oriented. Besides, the growth and prediction of good business growth will make investors more to rule out the risks that will be faced and more focus on the profitability of a company to reap the benefits. This study is in line with research conducted Hamizar (2016), Erni Irawati (2016) which concluded that the debt to equity ratio does not affect the price to book value

\section{The effect of Return on asset on Price to book value}

According to Sudana (2011) states that: Return On Assets (ROA) indicates a company's ability to use all of its assets to generate profit after tax. This ratio is important for the management to evaluate the effectiveness and efficiency of the company's management in managing all the assets of the company. The greater the ROA, the more efficient the use of corporate asset.

This is because high profitability shows good corporate prospects so as to trigger investor demand for shares. A positive response from the investor will increase the stock price and will further increase the company's value. The higher Return On Assets ratio will appeal to investors so they will be interested to invest in the company. The results of this study are in line with the research of Chaidir (2015) and Isabella Permata Dhani and A.A Gde Satia Utama (2017) which concluded that Return On Assets has a significant positive effect on Price to Book Value. 


\section{The effect Debt to equity ratio and Return on asset on Price to book value}

The result of $\mathrm{F}$ statistic test shows that debt to equity ratio and return on assets have significant effect on price to book value, this is caused by company value can be influenced by big leverage. Increased leverage indicates an increasing risk of investment. And a high profit in a company will have an impact on rising stock prices so as to increase the value of the company. The results of this study are in line with the results of previous research Rahmi (2014) which concludes that the capital structure and profitability together significantly influence the value of the company.

\section{CONCLUSIONS, IMPLICATION AND LIMITATIONS}

\section{Conclusions}

The results of the study concluded partially debt to equity ratio has no effect and not significant to price to book value, while return on aseets partially significant effect on price to book value. Simultaneously debt to euity ratio and return on assets have a significant effect on price to book value at food and beverage companies listed in Indonesia Stock Exchange period 2012-2016.

\section{Implications}

The implications of this research, Investors in the food and beverage sector should pay attention to the information issued by the company return on asset because the information affects the price to book value and so investors can take the right decision in investing. Management of food and beverage should manage the structure capital well by placing the funds into the investment profitable, by applying theory pecking order stating that debt is allowed when the sacrifice exceeds the profit earned, in order price to book value increases.

\section{Limitations}

The study was limited to a relatively short observation of 5 years with a limited sample (10 samples). With a limited sample then the result of R Square is low. With a low R Square of 23,9\%, it is necessary to add or adjust independent variables in future studies. In addition, the company's financial ratios used as the basis for predicting price to book value are only limited to two ratios, namely: debt to equity ratio and return on assets.

\section{REFERENCE}

Asnawi, Said Kelanadan Chandra Wijaya. Pengantar Valuasi. Jakarta: Salemba Empat, 2010.

Brigham dan Houston (2010). Dasar-Dasar Manajemen Keuangan. Jakarta : Salemba Empat, 2010.

Budihardjo, Andreas, dkk. Pijar-Pijar Manajemen Bisnis Indonesia. Jakarta: Prasetiya Mulya Publishing, 2011.

Chaidir. Pengaruh Struktur Modal, Profitabilitas, dan Pertumbuhan Perusahaan Terhadap Nilai Perusahaan Pada Perusahaan Sub Sektor Transportasi Yang Tercatat Di Bursa Efek Indonesia Periode 2012-2014. JIMFE (Jurnal Ilmiah Manajemen Fakultas Ekonomi) Volume 1 No. 2, EISSN 2502-5678 (2015) : 1-21.

Christiana, Irma dan Linzzy Pratami Putri. Faktor-faktor Yang Mempengaruhi Price To Book Value. Jurnal Studi Akuntansi Dan Keuangan. Vol 1. No 1, e-ISSN 2597-7601 (2017) : 11-20.

Fahla A, Rahmi (2014). Pengaruh Profitabilitas Dan Struktur Modal Terhadap Nilai Perusahaan Pada Perusahaan Sektor Agriculture Yang Terdaftar Di Bursa Efek Indonesia Periode 2010-2013. Skiripsi, Universitas Widyatama, Bandung, (2014)

Fahmi, Irham. Manajemen Investasi. Jakarta: Salemba Empat, 2015. 
Frederik, Priscilia Gizela, Sientje C. Nangoy dan Victoria N. Untu. Analisis Profitabilitas, Kebijakan Hutang dan Price Earning Ratio Terhadap Nilai Perusahaan Pada Perusahaan Retail Trade yang Terdaftar di Bursa Efek Indonesia. Jurnal EMBA1242 Volume 3 No.1 (2015 ) : 1242-1253

Hamizar. Analisis Faktor-Faktor Fundamental dan Faktor Teknikal Serta Pengaruhnya Terhadap Price to Book Value (Studi Empiris pada Perusahaan Pertambangan yang tercatat di Bursa Efek Indonesia periode 2010 - 2014 ). Jurnal Lentera Akuntansi Volume 2 No.1, ISSN 2339-2991 (2016)

Hani, Syafrida. Teknik Analisis Laporan Keuangan. Medan : UMSU Press, 2015

Harahap, Sofyan Syafri. Analisis Kritis atas Laporan Keuangan. Edisi 1. Jakarta: Rajawali Press, 2010.

Hariri, Syarifah. Pengaruh Return on Asset (ROA), Return on Equity (ROE) dan Kepemilikan Manajerial Terhadap Nilai Perusahaan (Studi Empiris Pada Perusahaan Manufaktur Di Bursa Efek Indonesia Periode 2009-2011) . Tesis Universitas Bina Nusantara Jakarta, 2012.

Hendra, Doni. Analisis Faktor-faktor Yang Mempengaruhi Price to Book VALUE (pbv): Studi Empiris Emiten Industri Barang Konsumsi Periode 2007-2010. Jurnal MIX Volume II No.3, (2012)

Irawati, Erni. Faktor Determinan Nilai Perusahaan Pada Perusahaan Manufaktur Yang Terdaftar Di BEI. Skripsi Fakultas Ekonomi Universitas Negeri Yogyakarta, 2016.

Juliandi, Azuar dan Irfan. Metodologi Penelitian Kuantitatif. Bandung: Cipta Pustaka Perintis, 2013.

Kasmir. Analisis Laporan Keuangan. Cetakan Ketiga. Jakarta : PT.Raja Grafindo Persada, 2012.

Mahfuda, Endang dan Suparno. Faktor Faktor Yang Mempengaruhi Nilai Perusahaan (Studi empiris Pada Perusahaan Manufaktur yang terdaftar di Bursa Efek Indonesia). JRKA Volime 2 Isue 2 (2016) : 56-75.

Meidiawati, Karina dan Titik Mildawati. Pengaruh Size, Growth, Profitabilitas, Struktur Modal, Dan Kebijakan Dividen Terhadap Nilai Perusahaan. Jurnal Ilmu Dan Riset Akuntansi Volume 5 No.2, (2016)

Moniaga, Fernandes. Pengaruh Struktur Modal, Profitabilitas Dan Struktur Biaya Terhadap Nilai Perusahaan Industri Keramik, Porcelen Dan Kaca Periode 2007-2011. Jurnal EMBA Vol 1, No 4, (2013).

Munawir. Analisis Laporan Keuangan. Yogyakarta : Liberty, 2010.

Perdana P, Tito, dkk. " Pengaruh Kinerja Keuangan dan Beta Saham Terhadap Price to Book Value Pada Perusahaan Real Estate dan Property yang Listed Di BEI Periode 2004-2006. Jurnal Studi Manajemen dan Organisasi Volume 2 No.2, (2007) : 81

Permata D, Isabella dan A.A Gde Satia Utama. Pengaruh Pertumbuhan Perusahaan, Struktur Modal Dan Profitabilitas Terhadap Nilai Perusahaan. Jurnal Riset Akuntansi Dan Bisnis Airlangga. Vol 2, No 1, (2017).

Prasetia, Ta'dir Eko, Tommy, Parengkuan dan S. Saerang Ivone. Struktur Modal, Ukuran Perusahaan dan Risiko Perusahaan Terhadap Nilai Perusahaan Otomotif yang Terdaftar di BEI. Jurnal EMBA. Volume. 2 No.2 (2014): 879-889.

Rodoni, Ahmad. Analisis Teknikal dan Fundamental pada Pasar Modal (Disertasi Hasil Penelitian). Edisi Pertama. Jakarta: Center for Social Economics Studies (CSES) Press, 2005.

Ross, Stephen A, et all. (2009), Pengantar Keuangan Perusahaan Corporate Finance Fundamental. Jakarta : Salemba Empat, 2009.

Suastini, Ni Made. Pengaruh Kepemilikan Manajerial Dan Pertumbuhan Perusahaan Terhadap Nilai Perusahaan Pada Perusahaan Manufaktur Di Bursa Efek Indonesia. E-Jurnal Ekonomi Dan Bisnis Universitas Udayana Vol 5, No 1, (2016).

Sudana, I Made. Manajemen Keuangan Perusahaan Teori dan Praktik. Jakarta : Erlangga, 2011.

Sugiyono. Metode Penelitian Adminsitrasi. Cetakan ke-18. Bandung : Alfabeta, 2010.

Syamsuddin Lukman. Manajemen Keuangan Perusahaan. Jakarta : PT.Raja Grafindo Persada, 2009. 